\title{
Consequences of Exposure to Domestic Violence for Children: A Systematic Review of the Literature ${ }^{1}$
}

\author{
Lélio Moura Lourenço \\ Universidade Federal de Juiz de Fora, Juiz de Fora-MG, Brazil \\ Makilim Nunes Baptista \\ Universidade São Francisco, Itatiba-SP, Brazil \\ Luciana Xavier Senra ${ }^{2}$ \\ Adriana A. Almeida \\ Caroline Basílio \\ Fernanda Monteiro de Castro Bhona \\ Universidade Federal de Juiz de Fora, Juiz de Fora-MG, Brazil
}

\begin{abstract}
The aim of this study was to carry out a systematic review of the literature on the consequences of exposure to domestic violence - DV for children. The period 2005-2011 was searched in Medline, Lilacs, Scielo, Web of Science, Dialnet, Redalyc, Google Scholar and PsycInfo, using the following descriptors: intimate partner violence, domestic violence, violence descriptors (physical, sexual, psychological), and child, exposure or witness. The author, country, methodology, journal and the consequences of exposure to DV were considered. 122 articles were selected. The United States and Brazil accounted for $78.7 \%$ of the publications, with children being the main victims (51.6\%). The major impacts upon children's health were posttraumatic stress and insecurity (75.8\%).
\end{abstract}

Keywords: family violence, violence in children, bibliometric

\section{Consequência da Exposição à Violência Doméstica Para Crianças: Revisão Sistemática da Literatura}

\begin{abstract}
Resumo: O objetivo deste estudo foi realizar uma revisão sistemática da literatura sobre as consequências da exposição à violência doméstica (VD) para crianças. Pesquisou-se o período 2005-2011, nas bases Medline, Lilacs, Scielo, Web of Science, Dialnet, Redalyc, GoogleSchoolar e PsycInfo, com os descritores intimate partner violence, domestic violence, descriptors violence (physical, sexual, psychological), e child, exposure or witness. Considerou-se autor, país, metodologia, periódico e consequências da exposição à VD. Selecionaram-se 122 artigos. EUA e Brasil totalizaram 78,7\% das publicações, sendo as crianças as maiores vítimas (51,6\%). As principais consequências de maior impacto na saúde das crianças foram stress pós-traumático e insegurança (75,8\%).
\end{abstract}

Palavras-chave: violência na família, violência na criança, bibliometria

\section{Consecuencias de la Exposición a la Violencia Doméstica a los Niños: Revisión Sistemática de la Literatura}

\begin{abstract}
Resumen: El objetivo de este estudio fue desarrollar una revisión sistemática de la literatura sobre las consecuencias de la exposición a la violencia doméstica (VD) para los niños. Fue investigado el período 2005-2011, en Medline, Lilacs, SciELO, Web of Science, Dialnet, Redalyc, GoogleSchoolar y PsycInfo, con los descriptores intimate partner violence, domestic violence, descriptors violence (physical, sexual, psychological), y child, exposure or witness. Fueron considerados autor, país, metodología, publicación y las consecuencias de la exposición a la VD. 122 artículos fueron seleccionados. EE.UU. y Brasil totalizaron el 78.7\% de las publicaciones, con los niños como las mayores víctimas (51.6\%). Las principales consecuencias de gran impacto en la salud de los niños fueron la depresión, el estrés postraumático y la inseguridad (75.8\%).
\end{abstract}

Palabras clave: violencia domestica, violencia en niño, bibliometria

\footnotetext{
1 Contributed to this article: Bruna Mattos Koga, Géssica Castellani Andrade, Jéssica Kiemy Hashimoto and Thiago Stroppa, the team of undergraduate and graduate students in Psychology from Universidade Federal de Juiz de Fora, members of the Núcleo de Estudos em Violência e Ansiedade Social (NEVAS).

2 Correspondence address:

Luciana Xavier Senra. Programa de Pós-graduação em Psicologia da Universidade Federal de Juiz de Fora. Rua Barão de São Marcelino, 555/506. CEP 360025-150. Juiz de Fora-MG, Brazil. E-mail: lu_senra@yahoo.com.br
}

The World Health Organization (WHO) defines the phenomenon of violence as "the intentional use of physical force or power, threatened or actual, against oneself, another person, a group or a community, which results or is likely to result in injury, death, psychological harm, or developmental loss or damage" (Krug, Dahlberg, Mercy, Zwi, \& Lozano, 2002, p. 5).

According to the WHO, there are three categories of violent behavior: self-inflicted violence, interpersonal violence and collective violence. Examples of the first type are: suicide, 
attempts to commit suicide and self-mutilation. Interpersonal violence occurs between people with family relationships (between partners, aimed at children or the elderly) or not (actions taken by strangers or colleagues in the community context). Collective violence is subdivided into political, social and economic. These latter subdivisions relate to possible motivations for acts committed by large groups of individuals or states, such as wars and even the denial of public access to essential services (Krug et al, 2002; Minayo, 2005).

With the exception of self-inflicted violence, the phenomenon can be depicted as follows: (1) physical (use of physical force with intent to harm others), (2) psychological (verbal or gestural, with the intention of humiliating, threatening, or causing damage to self-esteem), (3) sexual (the imposition of sexual practice against the wishes of the person or that causes their victimization) and (4) deprivation or neglect (lack or denial of care to those in need) (Ministério da Saúde, 2001b; Krug et al, 2002; Minayo, 2005).

\section{Domestic Violence}

Interpersonal violence - which specifically occurs within the family, the first context of children's socialization - is defined as domestic, intra-family or familial and is characterized by aggression among people with bonds of coexistence or kinship (Ministério da Saúde, 2001b).

With regard to violence in the family, women, elderly people and children are most often identified as the main victims (Stelko-Pereira \& Williams, 2010). In this sense, there are researchers and studies that aimed to study more closely the child who witnesses or is exposed to violence between their parents also called inter-parental violence, spousal or intimate partner violence, who may be heterosexual or homosexual (Saltzman, Fanslow, McMahon, \& Shelley, 2002; Archer, 2002; Krug et al, 2002; Centers for Disease Control and Prevention, 2007, Morbidity and Mortality Weekly Report, 2008).

The most commonly observed and described acts of aggression in the family or inter-parental context are physical, psychological and sexual in nature. They are characterized by slaps, punches and kicks, intimidation, humiliation and disqualification, or involve forced intercourse and other forms of coercion. Other forms of controlling behavior are also observed and understood as violence, such as monitoring the movements, isolation from friends and other family members, and restricting access to information and assistance (Krug et al, 2002; Instituto de Salud Publica de Madrid, 2004).

\section{Prevalence of Exposure to Domestic Violence}

When approaching the children exposed to inter-parental/domestic violence (DV), one must consider the phenomenon described above as actual and experienced by developing human beings emotionally linked to the perpetrators and victims. In these situations the family context is no longer seen as a primordial space of acceptance and support. On the contrary, it turns into a scenario of tension and obstacles to the child's development. According to Sani (2008), we must consider the fact that "children witness violence between people who are emotionally close and with whom he/she shares the same physical space” (p. 95). Maldonado and Williams (2005) point out that the "mere exposure is itself a form of child abuse" as merely witnessing the assault on his/her parent makes the child a victim of psychological violence.

Edleson, Shin and Armendariz (2008) point out that the exposure to or witnessing of DV encompasses multiple experiences. They argue that to witness, see, hear or even notice the mother's injuries and to become aware of them are also considered situations of exposure to family violence. The authors also specify that not only the awareness of the mother's victimization characterizes the phenomenon, but also the victimization of significant others who play the role of caregiver and with whom the child has a relationship of affection.

Intra-family and/or intimate-partner domestic violence occurs in intergenerational and hierarchical relationships and consists of forms of violence use as a strategy for conflict resolution or for discipline. It also includes the lack of basic care to their children. Another variation of psychological violence is the so called "witness to violence", which refers to violent situations witnessed by children/adolescent at home, school or in the community to which they belong. It is worth noting that a child or adolescent might be affected by more than one type of violence, especially in chronic and severe circumstances where these situations are related (Brazil, 2001). The scientific literature provides indicators showing that children might imitate and perform, in other contexts, the aggressive behavior by simply observing violent models such as the case of witnessing violence between the parents. Moreover, they can perceive aggressive behavior as an appropriate way to address and resolve conflicts (Bandura, Azzi, \& Polydoro, 2008; Bandura, Ross, \& Ross, 1961).

In order to evaluate the direct or indirect impact of violence upon children, particularly with regard to the exposure to family violence (domestic and/or between partners), it is necessary to keep in mind that childhood is a delicate and important stage of life, requiring significant emotional investments and social support. The care provided to children by the family, by other social groups and institutions greatly influences their chances of survival and dramatically improves their quality of life. In addition, caring functions as a reference value, which helps children to construct their own identity and form the first ideas about themselves, about others and the world (Deslandes, Assis \& Santos, 2005).

Despite the difficulty in measuring the situations of violence in the family context, data collected in 15 Brazilian capitals and the Federal District between 2002 and 2003 suggested an overall prevalence of psychological aggression of about $78.3 \%$ among couples. The occurrence of minor physical abuse affected $21.5 \%$ of the sample and serious physical 
Lourenço, L. M., Baptista, M. N., Senra, L. X., Almeida, A. A., Basílio, C., \& Bhona, F. M. C. (2013). Exposure to Domestic Violence.

assault 12.9\% (Reichencheim et al., 2006). With regard to the prevalence of exposure of children to such violence, a nationally representative study was conducted in $143 \mathrm{mu}-$ nicipalities between the 2005 and 2006 in which the results indicated that $26.1 \%$ of the sample were exposed to such situations. Of these cases $18.6 \%$ had witnessed severe parental violence (threat and assault combined) and $7.5 \%$ had witnessed moderate parental violence (threat of aggression) (Zanoti-Jeronymo et al., 2009).

Based on the aforementioned, in order to investigate the academic and scientific production on the subject, with the aim of understanding the manifestations of family violence and the impact for victims who witness the phenomenon, the aim of this study was to perform a systematic review of the literature through a bibliometric study on the consequences of exposure to domestic violence for children.

\section{Method}

We conducted a bibliometric study that aimed to analyze and evaluate (a) publishers of the works; (b) the chronological evolution of scientific production; (c) the productivity of the authors and institutions; (d) the growth of any field of science; and (e) the impact of the publications upon the national and international scientific community, needed for both scientific research and studies developing guidelines for the practice of professionals who deal with children and families (Reveles \& Takahashi, 2007).

An electronic search for articles indexed in the databases, in order to characterize the scientific literature on the exposure of children to domestic violence, was performed using the following indicators: (a) productivity per year, (b) productivity by country, (c) productivity by journal, (d) methodology, (e) most published authors, (f) main victims of domestic violence, (e) main problems associated with exposure to domestic violence, (f) events (definitions/descriptors) of domestic violence, and (g) key findings/research outcomes.

The electronic search was conducted in the following databases: Medline (publications which deals with health sciences in general), Web of Science (multidisciplinary database that aggregates content from journals of greater academic impact from different academic sectors); Dialnet (Iberian multidisciplinary database composed of journals and books from Spanish and Portuguese Universities); Redalyc (network of scientific journals of Latin America and the Caribbean, Portugal and Spain, including 758 journals in various areas, with social sciences and humanities the areas of greatest concentration); Google Scholar (database created by Google, which can search in multiple languages, providing links to libraries of various universities); and PsycInfo (offers psychological literature, linked to the American Psychological Association). These were chosen so as to obtain publications from the most diverse countries and to try to identify the impact of this theme in publications worldwide.

The following search terms were entered in each database: intimate partner violence, domestic violence, child witness or exposure, with descriptors violence (physical, sexual, psychological), which were searched in the titles and/ or abstracts of the publications. It is noteworthy that the use of the terminology in English aimed at reaching the broadest range of national and international publications in these data bases, which display dictionaries of search terms mostly in English and not just in their national languages.

The result of this search was refined by the exclusion of books, book chapters, monographs and theses. We selected only articles published from 2005 until the month of April 2011 (the date closest to the preparation of this manuscript), which totaled 389 publications. Repeated articles, those with limited access or not related to the subject matter, according to the reading of the Abstracts were discarded. The final result was a sample of 122 articles.

The articles selected for this systematic review were submitted to quantitative and qualitative analysis, considered complementary due to their approach and knowledge about a particular context or phenomenon capabilities (Reveles \& Takahashi, 2007). Initially, we quantified the information regarding year of publication, country of origin, journal, type of study and authors. Data on primary victims, issues/ factors associated with exposure to domestic violence, such as manifestation of violence and main research findings were obtained by reading the articles.

\section{Results}

Considering the production per year, there was a gradual increase in publications, which showed higher concentrations in the year 2010, given the fact that, with the year still in progress in the first quarter of 2011, the search was partial. Regarding the indexes by country, the United States, Brazil, Portugal, Spain and Canada were the countries, in descending order, which most published on the subject in the period studied, as shown in Table 1. The analysis of journals with articles on the topic is

Table 1

Publications by Country and Year in the Period 2005-2011 for $N=122$

\begin{tabular}{lccccc}
\hline Country & $\mathrm{N}$ & $\%$ & Year & $\mathrm{N}$ & $\%$ \\
\hline USA & 61 & 50 & 2011 & 13 & 13.7 \\
Brazil & 35 & 28.7 & 2010 & 56 & 51.6 \\
Portugal & 12 & 9.8 & 2009 & 12 & 7.4 \\
Spain & 5 & 4.1 & 2008 & 12 & 7.4 \\
Canada & 3 & 2.5 & 2007 & 12 & 7.4 \\
Bolivia & 1 & 0.8 & 2006 & 9 & 8.4 \\
Finland & 1 & 0.8 & 2005 & 8 & 6.6 \\
India & 1 & 0.8 & & & \\
Mexico & 1 & 0.8 & & & \\
Peru & 1 & 0.8 & & & \\
UK & 1 & 0.8 & & & \\
\hline
\end{tabular}

Note. The data of 2011 are biased because they include only publications up to the month of April. 
Table 2

Publications by Journal

\begin{tabular}{|c|c|c|}
\hline Journals & $\mathrm{N}$ & $\%$ \\
\hline Journal Interpersonal of Violence & 10 & 8.2 \\
\hline Revista da Faculdade de Ciências da Saúde & 8 & 6.6 \\
\hline Pediatrics & 6 & 4.9 \\
\hline Violence Victims & 6 & 4.9 \\
\hline Revista de Saúde Publica & 5 & 4.1 \\
\hline Arch Pediatr Adolesc Med & 4 & 3.3 \\
\hline Child Abuse \& Neglect & 4 & 3.3 \\
\hline Psicologia em Estudo & 3 & 2.5 \\
\hline Psicologia Reflexão e Crítica & 3 & 2.5 \\
\hline Ciência e Saúde Coletiva & 3 & 2.5 \\
\hline Saúde e Sociedade São Paulo & 3 & 2.5 \\
\hline Revista da Escola Enfermagem da USP & 3 & 2.5 \\
\hline Child Maltreatment & 2 & 1.6 \\
\hline Journal Epidemiol Community Health & 2 & 1.6 \\
\hline Issues Mental Health Nursing & 2 & 1.6 \\
\hline British Journal of Social Work & 2 & 1.6 \\
\hline Journal of Family Psychology & 2 & 1.6 \\
\hline Estudos de Psicologia & 2 & 1.6 \\
\hline Anales de Psicología & 2 & 1.6 \\
\hline Revista Brasileira de Enfermagem & 2 & 1.6 \\
\hline Revista Panamericana de Salud Publica & 2 & 1.6 \\
\hline
\end{tabular}

presented in Table 2. It is possible to identify the journals with the greatest impact on the research during the period and their respective percentage of participation in the sample: Journal of Interpersonal Violence (8.2\%), Journal of the Faculty of Health Sciences (6.6\%), Violence and Victims (4.9\%), Pediatrics (4.9\%), and Journal of Public Health (4.1\%).

The Journal of Interpersonal Violence is an English-language publication in which the aim is to discuss research and the treatment of victims and perpetrators of interpersonal violence. The Journal of the Faculty of Health Sciences is published by the Portuguese University Fernando Pessoa. Violence and Victims is a journal of The Family Research Laboratory of the University of New Hampshire (USA); Pediatrics is The journal of the American Academy of Pediatrics, which publishes monthly original research articles and clinical observations with translation into Italian, Portuguese, Spanish, Chinese and Polish. The Journal of Public Health is a journal of The School of Public Health, University of São Paulo.

The remaining journals each had $0.8 \%$ of the selected publications. They are: Journal of Adolescent Health,
Psicothema, JAMA, Clinical Child Family Psychology Review, Evaluation and Program Planning, Evidence-Based Mental Health, International Emergence Nursing, The Journal of Family Practice, Epidemiology, Journal of Child Psychology and Psychiatry, Children and Youth Service Review, American Economic Journal Applied Economics, Attachment \& Human Development, Journal of Social Work, Journal of Family Studies, British Journal of Social Psychology, Child \& Family Social Work, Psicologia: Ciência e Profissão, Cadernos de Pesquisa, Revista Ex Aequo, Análise Social, Ciência e Saúde Coletiva Revista brasileira de educação especial, Cadernos de Saúde Pública, Revista Brasileira Psiquiatria, Ciência e Saúde Coletiva, Análise Psicológica, Paideia, Pensando Famílias, Análise Psicológica, Aletheia, Interpersona, Paediatric and Perinatal Epidemiology, Archives of Pediatrics Adolescent Medicine, Journal of Family Violence, Social Forces, Ámbitos, BMC Public Health, Circunstancia, Indian Journal of Community Medicine, Indian Journal of Psychiatry, Interface (Botucatu), Población y Salud en Mesoamérica, Psicogente, Revista Latino-Americana de Enfermagem, Revista Brasileira de Ginecologia e Obstetrícia, Revista Mexicana de Ciencias Políticas y Sociales.

Regarding the type of methodology used and specified in each article, the following results were found: $26.6 \%$ of the publications were co-relational studies; $19.2 \%$ were literature reviews; $17.6 \%$ qualitative studies, and $12.7 \%$ prevalence studies. The remaining papers were: (a) $9 \%$ longitudinal studies; (b) 5.8\% incidence, case-control; (c) $4.3 \%$ cohort studies; (d) $1.6 \%$ prospective, propensity, controlled clinical trials.

Concerning the authorship of the publications, the survey also identified the percentage of publications by group of authors, as can be seen in Table 3. Author groups with the highest percentages were: (1) Sani AI, with 3.3\%, (2) McDonald R, Jouriles EN, Rosenfield D \& Corbitt-Shindler D, $2.5 \%$, and (3) Sani AI, \& Costa, VA, also with $2.5 \%$ of the publications. The other groups of authors for each publication had $0.8 \%$ of the total publications $(n=122)$. The authorship survey also allowed a percentual assessment of those who published as first, second and third authors. Sani, A. I. was the most published writer, with $4.92 \%$ of the articles published as first or second author, over the period 2005 to 2011. Other authors in similar authorship conditions were: Graham-Bermann with 2.46\%; Coutinho and Shraiber with 1.64\%; and France Jr. and Williams, both with $3.28 \%$ of total publications as the third author.

Concerning the type of victim, direct and/or indirect (exposure), of domestic, familial and/or inter-parental violence, $51.6 \%$ of the articles highlighted the child as the main victim, $25.4 \%$ indicated the adolescent as the main character of victimization, and in $13.9 \%$ of the sample ( $n=122$ publications) women were considered the victims; $9 \%$ of the articles did not specify any victimization. Regarding domestic violence, it should be noted that victimization is a broad concept that 
Lourenço, L. M., Baptista, M. N., Senra, L. X., Almeida, A. A., Basílio, C., \& Bhona, F. M. C. (2013). Exposure to Domestic Violence.

Table 3

Authors by Publication in the Period 2005-2011

\begin{tabular}{lcc}
\hline Group of Authors & N & $\%$ \\
\hline Sani, A.I. & 4 & 3.3 \\
Maldonado, D.P.A.; Williams, L.C.A. & 3 & 2.5 \\
Sani, A.I ; Costa, V.A. & 3 & 2.5 \\
McDonald, R; Jouriles, E.N.; Rosenfield, D; Corbitt- & 3 & 2.5 \\
Shindler, D. & & \\
Bayarri Fernandez, E; Ezpeleta, L; Granero, R; de la & 2 & 1.6 \\
Osa, N; \& Domenech, J.M. & & \\
Cohen, J.A.; Mannarino, A.P.; Iyengar, S. & 2 & 1.6 \\
Graham-Bermann, S.A; Perkins, S. & 2 & 1.6 \\
Hungerford, A; Ogle, R.L. \& Clements, C.M. & 2 & 1.6 \\
Rigterink, T; Fainsilber, Katz, L. \& Hessler, D.M. & 2 & 1.6 \\
Taylor, C.A; Lee, S.J; Guterman, N.B. \& Rice, J.C. & 2 & 1.6 \\
Carvalho, M.C.N. \& Gomide, P.I.C. & 2 & 1.6 \\
Finkelhor, D.; Turner, H; Ormrod, R. \& Hamby, S.L. & 2 & 1.6 \\
Milani, R.G. \& Loureiro, S.R. & 2 & 1.6 \\
Pinheiro, F.M.F. \& Williams, L.C.A. & 2 & 1.6 \\
Ribeiro, M. C. O. \& Sani, A. I. & 2 & 1.6 \\
Sani, A.I. \& Coutinho, M.J. & 2 & 1.6 \\
Jouriles, E. N.; McDonald, R.; Rosenfield, D.; & 2 & 1.6 \\
Stephens, N.; Corbitt-Shindler, D. \& Miller, P.C. & & \\
Wolfe, D. A. & 2 & 1.6 \\
Zortea, T.C. \& Tokumaru, R.S. & 2 & 1.6 \\
Szelbracikowski, A.C. \& Dessen, M. A. & 2 & 1.6 \\
Margolin, G. \& Vickerman, K. A. & 2 & 1.6 \\
\hline Note. For n 122 publicatins. & & \\
\hline
\end{tabular}

Note. For $n=122$ publications.

encompasses violence among people with affectionate attachment, which can be diverse and involve all sorts of people, such as men, women, children, adolescents and the elderly (García-Moreno et al., 2005). However, some authors use the term domestic violence to refer to the phenomenon of violence between intimate partners (Stelko-Pereira \& Williams, 2010), hence the importance of this type of analysis.

Among the problems associated with the exposure of children to domestic violence, the most significant ones had a direct impact on the physical and psychological health of the victims as well as on their daily lives. Predominant symptoms of depression, insecurity and Posttraumatic Stress Disorder (PTSD), also known as internalizing symptoms, were observed in $75.8 \%$ of the studies. Externalizing symptoms, which include adjustment problems/aggressive conduct, were identified in $32.6 \%$ of the sample. An impact on school performance and involvement in bullying were also prominent in $20 \%$ of the articles. With regard to manifestations of violence in the context of exposing children to domestic violence, among the 122 articles identified, 77 descriptions were analyzed for this phenomenon, reflecting eight different modalities, as can be seen in Table 4. Among these descriptions, 25 addressed physical violence; 22 sexual violence; 21 psychological violence; 4 economic violence; 2 abandonment or neglect; 1 emotional and verbal violence, and 1 addressed patrimonial violence.

\section{Discussion}

The study design enabled the construction of a landscape that characterizes, in some respects, the recent scientific knowledge about the exposure of children to domestic violence, a phenomenon of academic interest for the practice of professionals who work either with children or families. An increasing number of recent publications addressing the issue were detected. This fact confirms the prominence the issue has taken in the academic milieu. Indeed, various fields

Tabel 4

Types/Methods of Violence Expressed in the Context of Children's Exposure to DV

\begin{tabular}{lcc}
\hline & $\mathrm{N}$ & $\%$ \\
\hline Physical violence & 25 & 33 \\
Sexual violence & 22 & 29 \\
Psychological violence & 21 & 27 \\
Economic violence & 4 & 5.2 \\
Abandonment or neglect & 2 & 2.6 \\
Emotional violence & 1 & 1.3 \\
Verbal violence & 1 & 1.3 \\
Patrimonial violence & 1 & 1.3
\end{tabular}

Note. For $n=77$ publications describing/defining some form of violence.

of knowledge have focused on the phenomenon with highlights for the Health area, in which it is now considered a public health problem. The U.S. leads the academic output on the subject with half of the sample surveyed $(n=122$ articles published between 2005 and April, 2011 at the time of writing this manuscript). The second most productive country was Brazil with $28.7 \%$ of the published papers.

Regarding the most productive author, Ana Isabel Martinez Sani leads the position of first and second author, totaling $4.92 \%$ of the publications, the majority of them in collaboration with other writers. This author is a professor at the University Fernando Pessoa, Portugal, a country with an established research tradition on domestic violence. Sani (2006) warns that children exposed to violence between parents can be considered forgotten victims, since they do not fall into the direct victim category. However, she points out that this experience can be perceived as stressful and traumatic for the child and may trigger psycho-physiological changes, which can become severe, persistent and disruptive, features of the so-called Posttraumatic Stress Disorder. This disorder involves symptoms such as reactions of avoidance, numbing of responsiveness, and re-experiencing the traumatic situation (Costa \& Sani, 2007, 2008). Sani (2008) also found, through co-relational studies, fairly frequent feelings of anxiety, fear, insecurity, shame, aggressive behavior and depressive manifestations among children exposed to family violence. According to the author, and in agreement with 
Venturini et al. (2004) and Maldonado et al. (2005), households where family tension and conflict are present are environment where children may develop this kind of witnesses violence, with consequences ranging from physical marks and deprivation of basic needs (biological and psychological) to the emergence of physiological, emotional, cognitive and behavioral problems.

An important aspect to be considered in the study of violence in general is that the concept does not refer to a unique phenomenon. Its definition, forms of expression, level of tolerance by communities, and the role it plays in the lives of individuals present many differences. The multi-faceted forms of expressions for violence listed in this article are a good example of this claim (Table 4). The variety of methodologies that have been used to investigate the issue provides evidence of its fecundity. The observed predominance of co-relational studies (24.6\% of the sample) reflects the complexity of these events, which cannot be properly grasped simply through linear and causal relations. Indeed, a multiple correlation was observed in the studies highlighted in this article: an association of several variables in the social and health fields; the depth and the impact of violence on the lives of individuals, families and communities; and the need for intervention and prevention of violence, especially considering that a child or adolescent may be affected by different forms of violence under chronic and severe circumstances, which in the majority of cases are interconnected (Whiteside-Mansell, Bradley, McKelvey \& Fussell, 2009).

Still regarding the methodology, it is noteworthy that no intervention studies were found. However, the lack of publications does not necessarily mean that such studies were not performed. It may simply indicate that the complexity of the phenomenon and the lack of uniformity make it difficult to frame strategies of action, since the notion of violence has broad implications in different segments of individual and collective life and also relates to socio-cultural contexts in which the implementation of public policies to assist victims and perpetrators is especially problematic. Holt, Buckley and Whelan (2008), in a review study that sought to highlight the impact on the health and development of children and adolescents exposed to domestic violence, examined some important aspects concerning the phenomenon. According to the authors, the context of violence between the parents, in addition to being a form of emotional abuse, is considered a risk factor for physical and sexual victimization as well as for the neglect of the children. Regarding parental capability, the authors indicated that, in the context of inter-parental violence, authoritarianism, control and aggression tend to be child-rearing strategies adopted both by fathers who abuse their partners and by victimized mothers. These authors described the ambivalence caused in these children by circumstances in which a parent can be perceived as abusive and at the same time loving. Younger children may exhibit symptoms such as excessive fear, anxiety, problems with verbalizing emotions, aggressive behavior, possessiveness, stomach aches, insomnia, nightmares and bedwetting. As they grow older, they tend to seek explanations for the violent behavior of their parents and might blame themselves for the violence between their parents and even feel responsible for protecting the victims. Problems at school, in relationships with peers and in romantic relationships established during life may also be related to these experiences. The diversity of reactions to these situations may vary by age, gender, personality, role in the family, frequency, nature, intensity, severity and co-occurrence of different forms of violence to which the children/adolescents are exposed. These reactions can be minimized depending on the relationship with the parents and siblings, and the social support available, especially when there is a strong connection and attachment to an adult caregiver, usually the mother (Holt, Buckley \& Whelan, 2008).

Accordingly, one aim of this study was to identify the main problems for children associated with witnessing domestic violence. In our sample there was a prevalence of depressive symptoms, insecurity and posttraumatic stress disorder (75.8\%), followed by adjustment /behavior problems and aggression (32.6\%), and declining academic performance and bullying (20\%). Although the drop in academic performance and bullying problems were highlighted in only $20 \%$ of the analyzed articles, it is important to note that bullying (physical and psychological aggressive behavior among peers in the school environment, intentionally orchestrated and repeated over a period in order to cause damage to another) has emerged as a disturbing phenomenon due to the damage to those involved. This phenomenon has been associated with the context of domestic violence where children and adolescents are the direct or indirect victims, and tend to resort to aggression and violence as a naturalized form of peer relationship (Senra, Lourenço \& Pereira, 2011).

Regarding the physiological, emotional and psychological symptoms, authors such as Cui, Donnelan and Conger (2007), O’Donnel, Moreau, Cardemil and Pollastri (2010), Salisbury, Henning and Holdford (2009), and Shelton and Harold (2008), highlighted a deficit of basic care to children, as well as depression, posttraumatic stress, insecurity and low self-esteem. These disorders often tend to be neglected, as they are less easily observable in the child's behavior (Costa \& Sani, 2007). Grundy, Gondoli and Blodgett Salafia (2007), Whiteside-Mansell et al. (2009), McDonald, Jouriles, Tart and Minze (2009), Ghazarian and Buehler (2010), Graham-Bermann, Howell, Miller, Kwek and Lilly (2010), have all observed behavioral and adjustment problems, poor academic performance, reproduction of aggressive behavior, hostility and rejection among victims of violence in family, academic and social contexts.

These studies also revealed that, having been exposed to violence, some children showed a negative response to violence, avoiding aggressive and violent behavior with teachers and peers. Kelleher et al. (2008) argue that the literature indicates both poor school performance of children who witness violence between their parents and the existence of a greater emotional availability of mothers to their victimized children. Thus, caution is needed against rash 
Lourenço, L. M., Baptista, M. N., Senra, L. X., Almeida, A. A., Basílio, C., \& Bhona, F. M. C. (2013). Exposure to Domestic Violence.

generalizations. Given the unpredictability of reactions, it is not possible to establish a child's reactive model to domestic violence. However, there is a consensus on the understanding that children are active in the construction of the meaning of such experiences (Costa \& Sani, 2007a; Sani, 2008; Holt, Buckley \& Whelan, 2008, Graham-Bermann, Gruber, Girz \& Howell, 2009). Despite the variety of factors to be considered in the context of exposure to domestic violence and even the absence of symptoms or disruptive behaviors in some children, the impact of this experience is undeniable as a risk factor for the development of children and adolescents. In addition, witnessing such events may contribute for the intergenerational transmission of violence according to the research findings (Holt, Buckley \& Whelan, 2008).

\section{Final Considerations}

The paramount importance of this subject matter increases as the research findings indicate a general lack of strategic action in the analyzed data. It is essential therefore to identify the problem and adopt appropriate intervention strategies in the various public services meant to care for children, especially the healthcare and education systems. The knowledge of the context in which the child is inserted seems crucial to indicate methods of prevention and abridgment of the negative effects of violence. One must also consider that children who witness family conflicts are often inserted into the civil or criminal justice system. This factor may affect their psychological development, and therefore requires certain precautions prior to such a reality (Sani, 2008).

We could not end this paper without suggesting some guidelines for professionals who deal with the exposure of children to violence. The following are generally required: (i) professional training for the assessment and identification of cases; (ii) assistance and protection to be provided in the judicial system; (iii) practices adapted consistent with the child's development; (iv) an articulated safety net constructed in collaboration with other agencies and institutions involved in care for at risk children (Maldonado \& Williams, 2005; Sani, 2008).

Given the high rate of violence in different areas of Brazil, the Ministry of Health has launched programs that aim to support social, educational and health care for children and adolescents victims of indirect and/or direct domestic violence and/or inter-parental violence. The Policy for the Reduction of Morbidity and Mortality caused by Accidents and Violence (Brazil, 2001) includes the promotion of safe behaviors, monitoring of accidents and violence, training professionals for comprehensive action in the context of violence, and supports the development of new research in the area.

\section{References}

Archer, J. (2002). Sex differences in physically aggressive acts between heterosexual partners: A meta-analytic review. Aggression and Violent Behavior, 7(4), 313-351. doi:10.1016/S1359-1789(01)00061-1
Bandura, A., Azzi, R. G., \& Polydoro, S. (2008). Teoria social cognitiva: Conceitos básicos. Porto Alegre, RS: Artmed.

Bandura, A., Ross, D., \& Ross, S. A. (1961). Transmission of aggression through imitation of aggressive models. In C. D. Green, Classics in the history of psychology. Downloaded from http://psychclassics.yorku.ca/ Bandura/bobo.htm

Centers for Disease Control and Prevention. (2006). Behavioral risk factor surveillance system: 2005 summary data quality report. Downloaded from http://ftp.cdc.gov/ pub/data/brfss/2005summarydataqualityreport.pdf

Centers for Disease Control and Prevention. (2007). Cases of HIV infection and Aids in the United States and dependent areas, 2005. HIV/AIDS Surveillance Report, 17, 1-54.

Costa, V. A., \& Sani, A. I. (2007a). Crianças expostas ao trauma da violência familiar: Abordagens teóricas da sintomatologia de pós-stress traumático. Revista da Faculdade de Ciências da Saúde, (4), 210-221. Downloaded from http://bdigital.ufp.pt/ bitstream/10284/447/1/210-221FCHS04-13.pdf

Costa, V. A., \& Sani, A. I. (2007b). Sintomatologia de pósstress traumático em crianças expostas à violência interparental. Revista da Faculdade de Ciências da Saúde, (4), 282-290. Downloaded from http://bdigital.ufp.pt/ bitstream/10284/455/1/282-290REVISTA_FCS_04-2.pdf

Cui, M., Donnellan, M. B., \& Conger, R. D. (2007). Reciprocal influences between parents' marital problems and adolescent internalizing and externalizing behavior. Developmental Psychology, 43(6), 1544-1552. doi:10.1037/0012-1649.43.6.1544

Deslandes, S. F., Assis, S. G., \& Santos, N. C. (2005). Violências envolvendo crianças no Brasil: Um plural estruturante e estruturado. In Ministério da Saúde, Impacto da violência na saúde dos brasileiros (pp. 4377). Brasília, DF: Ministério da Saúde.

Edleson, J. L., Shin, N., \& Armendariz, K. K. J. (2008). Measuring children's exposure to domestic violence: The development and testing of the Child Exposure to Domestic Violence (CEDV) Scale. Children and Youth Services Review, 30(5), 502-521. doi:10.1016/j.childyouth.2007.11.006

García-Moreno, C., Jansen, H. A. F. M., Ellsberg, M., Heise, L., \& Watts, C. (2005). WHO multi-country study on women's health and domestic violence against women: Initial results on prevalence, health outcomes and women's responses. Geneva, Switzerland: World Health Organization.

Ghazarian, S. R., \& Buehler, C. (2010). Interparental conflict and academic achievement: An examination of mediating and moderating factors. Journal of Youth and Adolescence, 39(1), 23-35. doi:10.1007/s10964-008-9360-1 
Graham-Bermann, S. A., Gruber, G., Howell, K. H., \& Girz, L. (2009). Factors discriminating among profiles of resilience and psychopathology in children exposed to intimate partner violence (IPV). Child Abuse \& Neglect, 33(9), 648-660. doi:10.1016/j.chiabu.2009.01.002

Graham-Bermann, S. A., Howell, K. H., Miller, L. E., Kwek, J., \& Lilly, M. M. (2010). Traumatic events and maternal education as predictors of verbal ability for preschool children exposed to intimate partner violence (IPV). Journal of Family Violence, 25(4), 383-392. doi:10.1007/s10896-009-9299-3

Grundy, A. M., Gondoli, D. M., \& Blodgett Salafia, E. H. (2007). Marital conflict and preadolescent behavioral competence: Maternal knowledge as a longitudinal mediator. Journal of Family Psychology, 21(4), 675-682. doi:10.1037/0893-3200.21.4.675

Holt, S., Buckley, H., \& Whelan, S. (2008). The impact of exposure to domestic violence on children and young people: A review of the literature. Child Abuse \& Neglect, 32(8), 797-810. doi:10.1016/j.chiabu.2008.02.004

Instituto de Salud Pública. (2004). La violencia de pareja contra las mujeres y los servicios de salud. Informe del estúdio cualitativo. Madrid, España: Comunidad de Madrid.

Kelleher, K. J., Hazen, A. L., Coben, J. H., Wang, Y., McGeehan, J., Kohl, P. L., \& Gardner, W. P. (2008). Selfreported disciplinary practices among women in the child welfare system: Association with domestic violence victimization. Child Abuse \& Neglect, 32(8), 811-818. doi:10.1016/j.chiabu.2007.12.004

Krug, E. G., Dahlberg, L. L., Mercy, J. A., Zwi, A. B., \& Lozano, R. (Eds.). (2002). World report on violence and health. Geneva, Switzerland: World Health Organization.

Maldonado, D. P. A., \& Williams, L. C. A. (2005). O comportamento agressivo de crianças do sexo masculino na escola e sua relação com a violência doméstica. Psicologia em Estudo, 10(3), 353-362. doi:10.1590/S1413-73722005000300003

McDonald, R., Jouriles, E. N., Tart, C. D., \& Minze, L. C. (2009). Children's adjustment problems in families characterized by men's severe violence toward women: Does other family violence matter? Child Abuse \& Neglect,33(2), 94-101. doi:10.1016/j.chiabu.2008.03.005

Minayo, M. C. S. (2005). Violência: Um problema para a saúde dos brasileiros. In Ministério da Saúde, Impacto da violência na saúde dos brasileiros (pp. 9-41). Brasília, DF: Ministério da Saúde.

Ministério da Saúde. (2001a, 18 de maio). Portaria GM No. 737, de 16 de maio de 2001. Dispõe sobre a política nacional de redução da morbimortalidade por acidentes e violências. Diário Oficial da União, seção $1 e$.

Ministério da Saúde. Secretaria de Políticas de Saúde. (2001b). Violência intrafamiliar: Orientações para prática em serviço. Brasília, DF: Ministério da Saúde.
O’Donnell, E. H., Moreau, M., Cardemil, E. V., \& Pollastri, A. (2010). Interparental conflict, parenting, and childhood depression in a diverse urban population: The role of general cognitive style. Journal of Youth and Adolescence, 39(1), 12-22. doi:10.1007/s10964-008-9357-9

Reichenheim, M. E., Moraes, C. L., Szklo, A., Hasselmann, M. H., Souza, E. R., Lozana, J. A., \& Figueiredo, V. (2006). The magnitude of intimate partner violence in Brazil: Portraits from 15 capital cities and the Federal District. Cadernos de Saúde Pública, 22(2), 425-437. doi:10.1590/S0102-311X2006000200020

Reveles, A. G., \& Takahashi, R. T. (2007). Educação em saúde ao ostomizado: Um estudo bibliométrico. Revista da Escola de Enfermagem USP, 41(2), 245-250. doi. org/10.1590/S0080-62342007000200010

Salisbury, E. J., Henning, K., \& Holdford, R. (2009). Fathering by partner-abusive men: Attitudes on children's exposure to interparental conflict and risk factors for child abuse. Child Maltreatment, 14(3), 232242. doi:10.1177/1077559509338407

Saltzman, L. E., Fanslow, J. L., McMahon, P. M., \& Shelley, G. A. (2002). Intimate partner violence surveillance: Uniform definitions and recommended data elements. Version 1,0. Atlanta, GA: Centers for Disease Control and Prevention/National Center for Injury Prevention and Control.

Sani, A. I. (2006). Vitimação indirecta de crianças em contexto familiar. Análise Social, (180), 849864. Downloaded from http://www.scielo.gpeari. mctes.pt/scielo.php?script=sci_arttext\&pid=S000325732006000300007\&lng=pt\& nrm=iso

Sani, A. I. (2008). Crianças expostas à violência interparental. In C. Machado \& R. A. Gonçalves (Orgs.), Violência e vítimas de crimes: Crianças (Vol. 2, pp. 95-127). Coimbra, Portugal: Quarteto.

Senra, L. X., Lourenço, L. M., \& Pereira, B. O. (2011). Características da relação entre violência doméstica e bullying: Revisão sistemática da literatura. Gerais: Revista Interinstitucional de Psicologia, 4(2), 297-309.

Shelton, K. H., \& Harold, G. T. (2008). Interparental conflict, negative parenting, and children's adjustment: Bridging links between parents' depression and children's psychological distress. Journal of Family Psychology, 22(5), 712-724. doi:10.1037/a0013515

Stelko-Pereira, A. C., \& Williams, L. C. A. (2010). Sobre o conceito de violência: Distinções necessárias. In L. C. A. Williams, J. M. D. Maia, \& K. S. A. Rios (Orgs.), Aspectos psicológicos da violência: Pesquisa $e$ intervenção cognitivo-comportamental (pp. 41-66). Santo André, SP: ESETEC.

Venturini, F. P., Bazon, M. R., \& Biasoli-Alves, Z. M. M. (2004). Família e violência na ótica de crianças e adolescentes vitimizados. Estudos e Pesquisas em Psicologia, 4(1), 20-33. 
Whiteside-Mansell, L., Bradley, R. H., McKelvey, L., \& Fussell, J. J. (2009). Parenting: Linking impacts of interpartner conflict to preschool children's social behavior. Journal of Pediatric Nursing, 24(5), 389-400. doi:10.1016/j.pedn.2007.08.017

Zanoti-Jeronymo, D. V., Zaleski, M., Pinsky, I., Caetano, R., Figlie, N. B., \& Laranjeira, R. (2009). Prevalência de abuso físico na infância e exposição à violência parental em uma amostra brasileira. Cadernos de Saúde Pública, 25(11), 2467-2479. doi:10.1590/S0102-311X2009001100016

Lélio Moura Lourenço is an Associate Professor of the Graduate Psychology Program of the Universidade Federal de Juiz de Fora.

Makilim Nunes Baptista is a Professor of the Graduate Psychology Program of the Universidade São Francisco.

Luciana Xavier Senra is a PhD Student in Psychosocial Processes and Health of the Universidade Federal de Juiz de Fora.

Adriana Aparecida de Almeida has a Master's Degree in Psychosocial Processes and Health from the Universidade Federal de Juiz de Fora.

Caroline Basílio is a Psychologist and technical support scholarship recipient of the Universidade Federal de Juiz de Fora.

Fernanda Monteiro de Castro Bhona is a PhD Student in Psychosocial Processes and Health of the Universidade Federal de Juiz de Fora.

Received: Jul. $8^{\text {th }} 2011$

$1^{\text {st }}$ Revision: Jun. $6^{\text {th }} 2012$

Approved: Oct. $10^{\text {th }} 2012$

How to cite this article:

Lourenço, L. M., Baptista, M. N., Senra, L. X., Almeida, A. A., Basílio, C., \& Bhona, F. M. C. (2013). Consequences of exposure to domestic violence to children: A systematic review of the literature. Paidéia (Ribeirão Preto), 23(55), 263-271. doi: 10.1590/1982-43272355201314 


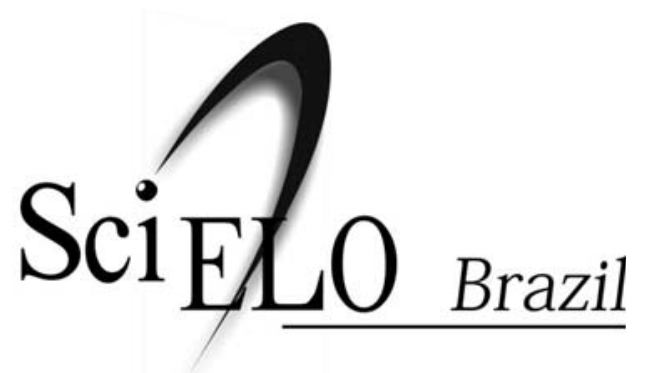

The SciELO interface provides easy access to the tables of content and to the full-text articles.

The SciELO interface also provides the retrieval of articles by the author's name, the words from title, abstract and descriptors, in addition to providing bibliometric indicators and consultation indicators.

The articles are enriched with connections to the LILACS, MEDLINE and PubMed databases.

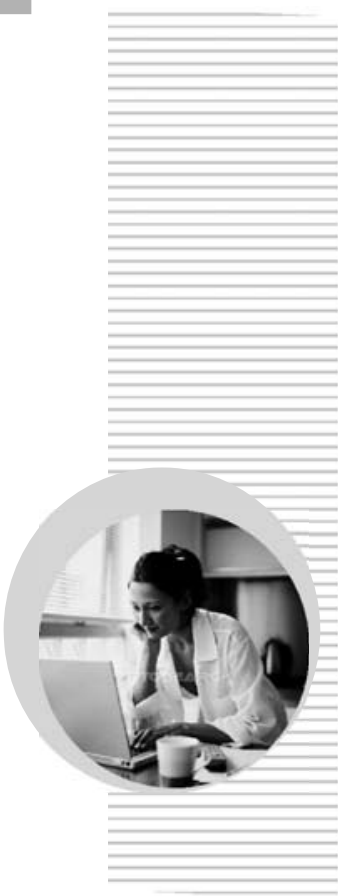

Paidéia (Ribeirão Preto) is a part of SciELO Brazil:

\section{www.scielo.br/paideia}

The SciELO interface provides access to a network of SciELO websites, gathering the major scientific journals of Latin America, Caribbean, Spain, Portugal and South Africa:

\section{www.scielo.org}

The electronic library is a project developed by the São Paulo Research Fundation (FAPESP), in partnership with the Latin American and Caribbean Center on Health Sciences Information (BIREME) and the National Council for Scientific and Technological Development (CNPq). 